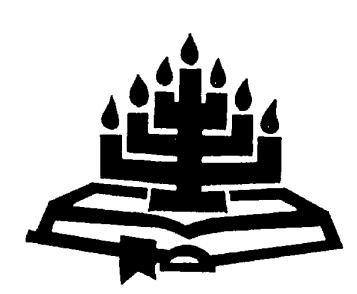

\title{
Skuldbelydenis in teologiese perspektief
}

\author{
J.H. van Wyk \\ Skool vir Kerkwetenskappe \\ Potchefstroomse Universiteit vir $\mathrm{CHO}$ \\ POTCHEFSTROOM
}

\begin{abstract}
Confession of guilt in theological perspective

For more than four decades (1948-1994) South African society was ravaged by a political dispensation of apartheid. This unjust system of legalised discrimination was widely typified as a sinful ideology and the Biblical justification of it as a heresy. It could be expected that the question would arise whether Christians, churches, politicians, government and other socio-economic institutions which supported and implemented apartheid should openly confess their sins of participation and/or negligence in this regard. The author argues that a confession of guilt in the South African context can be substantiated from a Biblical perspective, from church history and from the Reformed confessions. Confessions of guilt are an essential and indispensable part of Christian doctrine and Christian life.
\end{abstract}

\section{Inleiding}

Die vraag is uiters belangrik of daar oor die ideologie en praktyk van apartheid openbare skuldbelydenis gedoen behoort te word. Wie van mening is dat hierdie vraagstelling geïgnoreer, omseil of vermy kan word, leef in 'n vreemde wêreld van isolasie en wêreldmyding. So iemand vergeet dat, net soos die "teologie ná Auschwitz" (Jansen, 1983) 'n ander aard vertoon, die "teologie ná apartheid" in baie opsigte nie meer dieselfde kan wees nie. Die vraag kan immers nie vermy word nie hoe dit moontlik kon wees dat 'n land wat oorwegend uit Christene bestaan en waar die Reformatoriese teologie so 'n sterk invloed uitoefen, 'n slagoffer kon word van 'n politieke ideologie van onreg.

Dit is opvallend dat daar in Suid-Afrika in hierdie tyd - getrou aan die kerklike tradisie - twee soorte belydenisse ontstaan het: 'n geloofsbelydenis (die Belydenis van Belhar, 1986) asook skuldbelydenisse, waaronder die Skuldbelydenis uit Potchefstroom (voortaan SP), waaraan ons graag besondere aandag wil gee - 
soos ook aan die Ope brief (vgl. Van der Walt, 1997:26-28, 28-30). Trouens, in ons besinning oor die tema van skuldbelydenis sal ons veral op die SuidAfrikaanse toneel fokus, in besonder op die drie Afrikaanse kerke en dan veral die GKSA. Dit is byna onvermydelik dat dié artikel hier en daar 'n persoonlike toon sal aanneem.

Al drie die Afrikaanse kerke het besluit om nie 'n openbare skuldbelydenis te maak nie. Sodanige benadering is enigsins verrassend in die lig van die volgende bevinding van Olivier (1997:109): "Skuldbelydenis en versoening karakteriseer die hartslag van die gereformeerde belydenis en die lewe van die ware gelowige."

Die Algemene Kerkvergadering van die NHKA het op sy vergadering van 1998 besluit om 'n omvattende studie oor skuldbelydenis te doen wat oor drie jaar op die volgende vergadering behandel sal word (Beeld, 9 Okt. 1998:4). Reeds voor hierdie Kerkvergadering het I.W.C. van Wyk (1997:1399-1436) met sy boeiende artikel oor hierdie tema die saak behoorlik op die agenda van die Hervormde teologie geplaas.

In die NGK is breedvoerig oor die saak besin. Daar het 'n uitgebreide debat en selfs individuele en streekbelydenisse plaasgevind. Opspraakwekkend was die skuldbelydenis van W.D. Jonker ${ }^{1}$ tydens die Rustenburg-konferensie ${ }^{2}$ in 1990 en die aanvaarding daarvan deur aartsbiskop Desmond Tutu (Alberts \& Chikane, 1991:92). Jonker se optrede is begryplik as in gedagte gehou word dat "dit tot die wese van die kerk behoort dat hy belydenis van sonde sal doen" (Jonker, 1991:100). Hoewel die Algemene Sinode van die NGK 1994 teen 'n openbare skuldbelydenis besluit het, het die Ring van Stellenbosch (Van der Walt, 1997:22-26) en die Streeksinode van Wes- en Suid-Kaap 1997 ten gunste daarvan besluit. Die Dagbestuur van die Algemene Sinodale Kommissie het wel 'n dokument Die verhaal van die Ned. Geref. Kerk se reis met apartheid (1997) die lig laat sien waarin gestel word dat hierdie dokument as getuienis en belydenis verstaan moet word (NGK, 1997:3). Die belydeniskarakter kom egter nie in die dokument sterk na vore nie. Hierbenewens het individuele teoloë soos A. König (Die Kerkbode, 14 Mei 1996:11) en J. Müller (Die Kerkbode, 6 September 1996:13) hulle ten gunste van 'n openbare skuldbelydenis uitgespreek.

Die vraag ontstaan hoedanig die gesprek in die GKSA verloop het. Die Nasionale Sinode van Potchefstroom 1997 het besluit dat 'n beskrywingspunt wat vir 'n

$1 \quad$ Hierin het Jonker ondersteuning gevind in die dokument Kerk en samelewing (Jonker, 1991:100; vgl. NGK, 1997:54).

2 Volgens Kistner (1996:65) gaan “die Rustenburger Erklärung mit ihrem Schuldbekenntnis viel weiter als das Stuttgarter Schuldbekenntnis" - dit was immers 'n plaasvervangende belydenis. Dit verander natuurlik niks aan die feit dat aan die dokument bepaalde mankemente kleef, byvoorbeeld dat dit net deur leiersfigure uitgespreek was. 
verantwoording ('n skuldbelydenis) gevra het, nie genoegsame motivering gehad het op grond waarvan die Sinode 'n skuldbelydenis sou kon uitspreek nie (GKSA Acta, 1997:884-884; vgl. Van Wyk, 1997a:24-25; 1997b: 4-6). Die Sinode het hom nie oor die regmatigheid al dan nie van 'n skuldbelydenis uitgespreek, soos sommige foutiewelik meen nie, nog minder daaroor dat 'n Gereformeerde lidmaat dit nie mag doen nie, maar wel daaroor dat die betrokke beskrywingspunt in gebreke gebly het om aan te toon "oor watter besluite die Sinode hom moet verantwoord” (GKSA Acta, 1997:884-885).

In Oktober 1997 verskyn daar egter in die blad Woord en Daad 'n skuldbelydenis van vier Gereformeerde lidmate, uitgereik in persoonlike hoedanigheid (vgl. ook Van der Walt en Venter, 1998). Hierdie skuldbelydenis het uiteenlopende reaksie uitgelok. Sommige het baie negatief gereageer ${ }^{3}$ terwyl ander weer meer positief gerespondeer het ${ }^{4}$.

In sy reaksie - waaroor later meer - sny Gerrie Snyman (1997; vgl. Beeld, 10 Okt. 1997:11) 'n baie belangrike saak in verband met Skrifbeskouing en Skrifverklaring aan as hy opmerk: "As bely word dat apartheid verkeerd is, hoe kan die histories-letterlike benadering (van die Bybel) nog gehandhaaf word?"

Die debat is geopen, menings is gewissel, kritiek is uitgespreek en dit is onvermydelik om verder teologies oor die onderwerp te besin. Is 'n openbare skuldbelydenis 'n Fremdkörper in die gereformeerde geloofstradisie of behoort dit tot die wese daarvan? Aan hierdie en ander aanverwante vrae word vervolgens verdere aandag bestee.

\section{Teologiese besinning}

\subsection{Die vraag na die teologiese motivering vir 'n skuldbelydenis}

In 'n gereformeerd-teologiese benadering tot die vraag na 'n skuldbelydenis neem die Skrifgetuienis uiteraard 'n sentrale plek in en speel dit 'n deurslaggewende rol. Vandaar hierdie noodsaaklike hoewel beperkte besinning oor teologiese grondslae. Ek merk hierby op dat in hierdie subafdeling slegs enkele breë uitgangspunte aangestip sal word en dat ander relevante Skrifgegewens by ander subhoofde ter sprake gebring sal word.

3 Vgl. in hierdie verband G.J.C. Jordaan in Beeld 8 Oktober 1997:11 en in die Algemene Kerkbode, 14/15 November 1997:7; die redakteur van Die Kerkpad, November 1997:18 en Januarie 1998:2; Buys, 1998:2-4 (en my opmerkings in Waarheid en Dwaling, November 1997:3-4) asook D.C. Coetsee in Woord en Daad (Coetzee, 1997:13, 20-22).

$4 \quad \mathrm{Vgl}$ in hierdie verband die opmerkings van J.M. Vorster en T. van der Walt in Beeld, 8 Oktober 1997:11 asook Tim du Plessis in Beeld, 17 Oktober 1997:10. 
Wanneer die Skrifgegewens nagegaan word, gaan dit nie bloot daarom dat (op eksemplariese wyse) op 'n aantal Bybelse figure gefokus word nie, maar dit gaan oor die totale struktuur van die Ou- en Nuwe-Testamentiese boodskap, dit gaan oor 'n lewe van ootmoed coram Deo, 'n lewe waarin die jirat Jahveh sentraal staan en waarin bekering, skuldbelydenis, vergewing en versoening onmisbare komponente is.

\section{- Ou-Testamentiese gegewens}

Wat die Ou-Testamentiese gegewens betref, kan op die volgende gewys word. Die motief van skuldbelydenis kom veelvuldig in die Ou Testament voor en kerngedeeltes wat hieroor handel, is onder andere die volgende: Levitikus 26:4041; Esra 9:6-15; Nehemia 1:5-11; 9:6-37; Daniël 9:4-19. Dit is baie opvallend dat die grondbetekenis van skuldbelydenis (jadah en toda) weergegee kan word met loof en dank (Westermann, 1978:675; Olivier, 1997:105; vgl. Jafta, 1989:46-57). Skuldbelydenis aksentueer dus sowel 'n houding van ootmoed as lofprysing teenoor die Here. Skuld en sonde is so deel van die menslike bestaan dat die ganse geskiedenis van Israel beskryf sou kon word vanuit die perspektief van sonde (vgl. Neh. 9:16-28; Eseg. 20:8; Kessler, 1996: 29 e.v.).

Sonde moet egter bely word. Dit is van die grootste belang dat sonde (wat ontken kan word, Klaagl. 5:7; Eseg. 18:20) erken moet word, asook beken (bely) moet word. "Kommt es dann zur Erkenntnis eigener Schuld, muss auf die Erkenntnis der Schuld ihr Bekenntnis folgen. Denn nur bekannte Schuld is erkannte Schuld" (Kessler, 1996:30). Wie die reddende genade van God erken, moet noodwendig sy eie misstappe en sonde erken; wie sy misstappe bely (beken), erken (bely) God teen wie hy oortree het (Westermann, 1978:675, 681).

Dit is verder insiggewend dat terwyl sondebelydenis in die wet, geskiedskrywing en profete deur verteenwoordigers van die volk uitgespreek word, daar by die poësie en wysheid 'n opvallende individualisering intree en individue aan die woord kom (Aschermann, 1970:151). Dit is moontlik om namens sondaars skuld te bely, maar dit is ook moontlik om dit baie persoonlik te doen (Ps. 51). Die noodsaak van skuldbelydenis word opgeroep vanweë die mens se ongehoorsaamheid aan die profetiese woord en daarmee aan die Woord van God self (Neh. 9:26; Dan. 9:6).

\section{- Nuwe-Testamentiese gegewens}

Ten opsigte van die Nuwe-Testamentiese gegewens kan die volgende opgemerk word: Die begrip (ex-)homologeomai beteken belowe, beweer, betuig, geloof bely, maar ook sonde bely (Michel, 1967:199-220; vgl. Nicol, 1989:58-69; Strobel, 1968). Skuldbelydenis kry ' $n$ vaste plek in die verkondiging van Jesus en van die oud-Christelike gemeente, veral waar die gemeenskap met die broeder geskaad is (Aschermann, 1970:151). Johannes die Doper roep op tot 
skuldbelydenis as teken van bekering (Mark. 1:5; Matt. 3:6; vgl. Hand. 19:18) (Michel, 1967:215).

Die skuldbelydenis waartoe opgeroep word, is 'n skuldbelydenis teenoor God (1 Joh. 1:9), maar ook 'n belydenis teenoor die broeder (Jak. 5:16). Terwyl vergifnis nie plaasvind op grond van skuldbelydenis nie, vind dit blykbaar ook nie daarsonder plaas nie (1 Joh. 1:9).

Die hele evangelie kan in twee woorde saamgevat word, naamlik "bekering en vergewing" (Luk. 24:47), terwyl by bekering noodwendig gedink moet word aan skuldbesef en skuldbelydenis.

\subsection{Die vraag na die noodsaak van 'n skuldbelydenis}

Die vraag wat hier aan die orde gestel word, is die vraag of ons in die ideologie van apartheid werklik met 'n sonde van so 'n aard en omvang te doen gehad het dat dit 'n openbare skuldbelydenis regverdig. Moet apartheid inderdaad as "'n misdaad teen die mensheid" 5 beskou word waaroor (dus) skuld bely behoort te word?

Op die vraag na die noodsaak van 'n skuldbelydenis kan ten minste vier antwoorde gegee word:

Ten eerste omdat die Here God daartoe oproep. Toe ons die Skrifgegewens nagegaan het, het dit duidelik geword dat die Here God van die mens 'n ootmoedige lewenswandel vra (Miga 6:8), 'n lewe wat gekenmerk word deur sondebesef en skuldbelydenis. Wie die evangelie wil verstaan, moet die sonde verstaan en wie van genade wil lewe, moet sy sonde bely. Die Christelike lewensbeskouing ken geen ander moontlikheid nie.

Ten tweede is 'n skuldbelydenis noodsaaklik omdat die kerk daartoe aanmoedig (vgl. Berkouwer, 1960:248-266). Die gereformeerde belydenisskrifte is deurdrenk van 'n diepe sondebesef. Die Heidelbergse Kategismus neem dit as vertrekpunt - om salig te lewe en te sterwe - dat iemand 'n diepe kennis van sy ellende sal hê (HK 2:3). In die bekende Nagmaalsformulier resoneer die motief dat elkeen oor sy sonde en vervloeking moet nadink, sodat hy homself kan mishaag en hom voor God kan verootmoedig. Die sondes waarvan die Formulier praat, is seker nie net beperk tot persoonlike en kerklike sondes nie, maar sluit inderdaad ook sosio-politieke, ja, alle denkbare sondes in. Die gereformeerde tradisie ken geen selektiewe sondebegrip nie.

5 Giliomee (1998:16) is van mening dat 'n VN-Konvensie in 1976 apartheid tot 'n misdaad teen die mensdom verklaar het, maar dat die Konvensie deur feitlik geen Westerse land onderskryf is nie. 
Ook in sinodebesluite kom die gedagte van skuldbelydenis na vore. Ons het reeds daarop gewys dat die sinodale besluit van 1997 hoegenaamd nie 'n prinsipiële uitspraak daarteen is nie (asof dit nooit mag voorkom nie). So 'n besluit sou trouens in stryd gewees het met 'n besluit van Sinode 1970 waarop die SP hom direk beroep en wat soos volg lui:

Christene behoort aangespoor te word om hulle gemeenskaplike betrokkenheid in skuld saam met 'n wêreld wat deur sondige skeidinge en houdinge geskeur is, te erken; hulle behoort opgeroep te word om hulle eie sondes in hierdie verband te bely en om herstelling (restitusie) te bewerkstellig deur Christus in die weg van liefde te volg (GKSA Acta, 1970:63).

Die kritiese vraag moet in hierdie verband gestel word of die skuldbesef en skuldbelydenis van Gereformeerdes met die verloop van tyd nie verswak is vanweë die langdurige gebrek daarvan in die erediens nie. Juis daarom moet dit hartlik verwelkom word dat Sinode 1997 hierdie wesenlike deel van die erediens (Deddens, 1995:491-529) weer in ere herstel het (GKSA Acta, 1997: 745-749).

Ten derde was 'n skuldbelydenis noodsaaklik vanweë die grootte van die oortreding. Die konklusie is onvermydelik dat apartheid sonde was en wel van sodanige aard en omvang dat daaroor eenvoudig in die openbaar skuld bely moes word. Sonde kán in politieke strukture vasgroei en so onsigbaar raak dat dit byna nie opgemerk word nie (Van Wyk, 1986:25, 192). Daar kan geen twyfel daaroor bestaan nie dat apartheid 'n sisteem van gewettigde sosiale onreg was (vgl. breedvoerig Van Wyk, 1993:39-60; Van der Walt, 1995:26-36). Dis opvallend dat ook die voormalige staatspresidentsvrou, Marike de Klerk, tot hierdie gevolgtrekking gekom het (Maartens, 1998:166-168). Volkome tereg het die Sinode van die GKSA 1991 besluit - en die SP beroep hom daarop - dat "die ideologie van apartheid 'n sonde en die Bybelse regverdiging daarvan 'n dwaling is" (GKSA Acta, 1991:160/169).

Apartheid was 'n politieke, kerklike en morele sonde. Getuienisse en vertellings voor die Waarheids- en Versoeningskommissie lewer onteenseglik bewys van die hemelskreiende wyse waarop met menselewens omgegaan is. Hieroor het Antjie Krog in haar boek Country of my skull (1998) breedvoerig verslag gedoen. Mense, geskape na die beeld van God, is by talle geleenthede sonder verhoor aangehou, gemartel, vermoor en uitgewis. Vlakplaas, 'n doodgewone plaasnaam, het 'n simbool geword van 'n diaboliese projek. In die naam van apartheid is soveel grusame misdade gepleeg dat daaroor eenvoudig nie geswyg mag of kon word nie. Dit was 'n misdaad teen die mense van Suid-Afrika. Groot gebeure staan uit: die moord op Steve Biko (1977), die Pepco-drie (1985), die Cradockvier (1985), die bomme op die ANC-kantore in Londen (1982), Cosatu-Huis (1987) en Khotso-Huis (1988) (vgl. breedvoerig TRC, 1998, 2:42-312). 
Dit spreek vanself dat iemand wat in 'n houding van onkunde of verontskuldiging die standpunt huldig dat apartheid "tog nie so erg was nie", hom/haar geensins sal kan inleef in die styl en toonaard van die SP nie, ja, hy/sy mag dit onbegryplik en selfs verwerplik vind.

Die vraag kan gestel word of iemand nie sou kon sê: "Ek het nie geweet nie; ek is onskuldig". Dit bring die vraag van kollektiewe skuld na vore waar gewoonlik, in aansluiting by Karl Jaspers, die volgende onderskeidings hanteer word (Jaspers, 1947:10-14, 29-58; vgl. Honecker, 1986:134; Villa-Vicencio, 1998:187-188; Krog, 1998:97): kriminele skuld (die werklike oortreders en moordenaars); politieke skuld (politici wat 'n beleid ontwerp, propageer en implementeer asook burgers wat doelbewus of willoos navolg); morele skuld (dit sluit almal in wat doelbewus, onwillig of uit nalatigheid betrokke is, en deur die sisteem bevoordeel word); metafisiese skuld (uiteindelik is almal skuldig). Hoewel daar graduele verskille in skuld is, kan kollektiewe skuld nie ontsnap word nie (vgl. Jaspers, 1947:52-57). Op een of ander verborge wyse is almal skuldig en is selfs die huidige geslag betrokke by en verantwoordelik vir die sonde van die voorgeslag (vgl. Luk. 11:50-51). Daar is wel graduele verskille in die oortreding en dus graduele verskille in die skuld (Matt. 11:20-24), maar almal bly volledig skuldig.

Hoe is dit moontlik dat iemand nie kon geweet het nie nadat die NG Sendingkerk die Suid-Afrikaanse situasie in so 'n ernstige lig beskou het dat 'n nuwe geloofsbelydenis in 1986 nodig geag is? Hoe is dit moontlik, nadat die Gereformeerde ekumene veral sedert 1970 apartheid herhaaldelik afgewys het terwyl die Christian Reformed Church of North America in 1989 selfs sy bande met die GKSA gesuspendeer het? Hoe is dit moontlik, nadat die Gereformeerde Sinode Middellande in 1983 te Mesi-A-Matala hom skerp teen apartheid uitgespreek het (Van Wyk, 1993:54)? Ja, hoe is dit moontlik, nadat talle Suid-Afrikaanse skrywers voordurend in hul romans op talle wandade in die samelewing gewys het? Hier kan slegs verwys word na romans soos byvoorbeeld André P. Brink se Droë wit seisoen $(1979: 36-37,51,81,91)$ asook sy Die muur van die pes (1984:229, 257). Reeds in 1979 het Elsa Joubert met haar boek Die swerfjare van Poppie Nongena aandag gevra vir die verwoestende gevolge van apartheid op die gesinslewe van swart mense.

Hierby kom nog die verswarende omstandighede dat die kerk en teologie aan apartheid 'n teologiese onderbou voorsien het (vgl. NGK 1997:6-11; Van Wyk, 1993:39-60). Die kritiese distansie tussen kerk en volk het in die teologiese besinning en kerklike besluite verlore geraak en kerke was blind vir die ideologiese gevare van (oordrewe) nasionalisme en etnosentrisme. Die staatkundige model van aparte volkstate het die model van aparte volkskerke (of volkerekerke) wat in die Afrikaanse kerke in 'n mindere of meerdere mate ingang gevind het, medebepaal, maar daarmee het die koinonia tussen (wit en swart) kerke ernstig in gedrang gekom. Die kerk was - sonder dat die meeste daarvan bewus was en 
deur sommige selfs ontken is - op 'n groot skaal gepolitiseer. Wie van mening is dat slegs 'n geïntegreerde kerk polities gemotiveer is, maar aparte kerke nié, maak hom skuldig aan 'n onverantwoordelike naïwiteit.

Hierby moet ook verwys word na die sonde van nalatigheid, die sonde om nie hard genoeg en lank genoeg teen die verkeerde te getuig het nie (vgl. Barth, 1978:452-546). Die Skrif is hieroor duidelik: "As iemand weet wat die regte ding is om te doen en hy doen dit nie, is dit sonde" (Jak. 4:17; vgl. Luk. 12:47). Dit is uit die inhoud van sowel die SP as die Ope brief duidelik dat die sonde van nalatigheid daarin 'n belangrike rol speel.

Die feit dat in die SP spesifiek na die sonde van die Afrikaners verwys word, is nie bedoel om slegs Afrikaners die sondebok vir alle misdade te maak nie. Hoewel nooit vergeet mag word dat Afrikaners die argitekte van ideologiese apartheid was nie, het die ANC en ander bevrydingsbewegings ook talle wandade gepleeg waaroor skuld bely behoort te word. Hier kan slegs verwys word na die aanval op die King William's Town golfklub, die Pretoria-straatbom (1983), die St. Jameskerk (1993) en Shell House (1994) (vgl. breedvoerig, TRC, 1998, 2:325-392). Dan is nog nie eers verwys na halssnoermoorde en die misdade wat in buitelandse strafkampe plaasgevind het nie.

Die feit dat in die SP spesifiek die sondes van die Afrikaners betrek word, beteken nie dat vergeet word van die sondes teen die Afrikaners nie, byvoorbeeld dié tydens die Tweede Anglo-Boereoorlog. Dit bly steeds selektiewe moraal dat Engelse kerke en predikante die Afrikaner vir sy sonde van apartheid veroordeel het, maar nooit verskoning gevra of skuld bely het oor die wandade wat die Engelse teenoor die Afrikaner tydens die genoemde oorlog gepleeg het nie (Van Wyk, 1984:77). Eerwaarde Peter Storey het tereg sy afkeur en afgryse uitgespreek oor die bomaanval op Khotso-huis in 1988 - "dit was 'n daad van staatsterrorisme" (Beeld, 4 Junie 1998:2). Maar hoe vergelyk een aanslag op een kerkkantoor met die groot aantal kerkgeboue wat in die Tweede AngloBoereoorlog afgebrand is (vgl. Pretorius, 1998:31)? Was dit nie ook misdade van staatsterrorisme nie? Die naaste waaraan dit aan 'n verskoning van Engelse kant in hierdie verband gekom het, en waarvan ek bewus is, met die uitsondering van Emily Hobhouse (Cameron \& Spies, 1991:215), is die opmerking van De Gruchy (1991:107) in verband met "the Anglo-Boer War with its senseless killing, suffering, and destruction of the land"6. Dit is nie vergesog nie om die vernedering van die Afrikaner tydens hierdie oorlog te sien as die geboorte-uur

6 De Gruchy (1998:7-8) is in 'n resente geskrif nog meer uitgesproke. Hy verwys daarin na die "atrocities of the concentration camps" en dat dit (destyds) die beleid van die Britse regering was om die Afrikanerkultuur te vernietig. "Tragically, the role of the English-speaking churches in all this was entirely jingoistic - not only was there no criticism of the imperial war effort, there was total support for it." 
van Afrikaner-imperialisme, soos wat die vernedering van die Duitsers by die Vrede van Versailles (1919) die geboorte-uur was van Nazisme twee dekades later?.

In die vierde plek: nie net die grootheid van die uiterlike misdade nie, maar ook die innerlike gewete noodsaak 'n skuldbelydenis. Iemand bereik 'n punt dat hy moet sê: Hierdie verborge skuld vreet so aan my gewete, dit verteer my innerlike sodanig dat ek moet sê: Ek het teen God en my naaste gesondig (Luk. 15:18, 21)! Dit gaan met hom soos met Dawid: "Toe ek oor my sonde geswyg het, het my liggaam uitgeteer ..." (Ps. 32:3). Psigologies gesien, skep onderdrukte en onverwerkte skuldgevoelens 'n spiritueel plofbare toestand; verdringing van skuldgevoelens werk verslawend en veroorsaak sielsiekte. Wentsel (1995:426) merk tereg op dat die skuld van die verlede verwerk moet word anders word dit herhaal; uit die gedane onreg van die verlede moet geregtigheid vir die toekoms geleer word.

Wie deur die Heilige Gees aangeraak word, neem die sondeskuld volledig ernstig en doen daarvan belydenis voor God en die naaste. Die Heilige Gees oortuig van sonde en onreg.

In hierdie verband moet baie duidelik tussen skuldkompleks en skuldpsigose enersyds en skuldbesef andersyds onderskei word (Van Wyk, 1986:25; vgl. Smit, 1996:113-116). Skuldkompleks dui op 'n toestand van psigologiese versteurdheid en wanbalans, terwyl 'n welbewuste skuldbesef ' $n$ inherente deel van die Christelike leer en lewe uitmaak. Waar dit ontbreek, kan immers nie meer met vrymoedigheid gebid word om vergewing van sondes nie (Matt. 6:12).

Skuldbesef en skuldbelydenis vorm 'n inherente deel van die Christelike tradisie, te sien vanaf Augustinus, met sy Confessiones, oor Calvyn tot in die twintigste eeu waar dit veral deur Bonhoeffer beklemtoon is - waaroor later meer.

\subsection{Die vraag na die inhoud van 'n skuldbelydenis}

Oor die vraag wat die inhoud van 'n skuldbelydenis behoort te wees, kan dit waardevol wees om na twee sodanige dokumente self te kyk, naamlik die SP en die Ope brief. In hierdie verband moet deeglik daarmee rekening gehou word dat die twee dokumente totaal onafhanklik van mekaar ontstaan het. Toe die Ope brief verskyn het, was die eerste ontwerp van die SP reeds gereed. Die twee dokumente vertoon ook elk 'n eie struktuur. In die Ope brief loop skuldbelydenis en verantwoording deurmekaar terwyl hierdie twee elemente in die SP sorgvuldig

7 Vgl. hier die uitspraak van M. Lapsley soos aangehaal deur Ruda Landman in Insig (1998:34):

"As daar 'n waarheidskommissie was vir die Afrikaners na die Anglo-Boereoorlog het ons miskien nooit apartheid gehad nie." 
onderskei is. In die SP val die klem op die skuldbelydenis, terwyl die "verantwoording" eintlik maar as 'n voetnoot bedoel is. In die SP resoneer ook iets van die Stuttgart Belydenis van 1945. Vergelyk hier die uitspraak van Stuttgart dat "wir nicht mutiger bekannt, nicht treuer gebetet, nicht fröhlicher geglaubt und nicht brennender geliebt haben" (Greschat, 1982:102, vgl. Kessler, 1996:41) met die SP wat in 1.2 bely "dat ons nie moedig genoeg getuig, nie getrou genoeg gebid, nie daadwerklik genoeg geglo, nie vurig genoeg liefgehad en nie genoegsame invoeling gehad het nie ...".

In die SP word skuld bely teenoor God en die naaste en wel oor die vernietigende rol wat die ideologie van apartheid in Suid-Afrika uitgeoefen het (1.1), soos dit te sien is in die skending van fundamentele menseregte (1.2). Veral die sonde van nalatigheid en traagheid word openlik bely $(1.1,1.3)$. Die koersloosheid in krisistye sinspeel daarop dat wat bedoel was as "koers in die krisis" dit in die geval (van politieke koers) juis nié was nie (1.2). Vergifnis word van die verontregte medegelowiges gevra $(1.3,1.4)$ en die onderneming word gegee om sover moontlik vergoeding te gee (1.4). Die doel van die skuldbelydenis is gerig op vergewing, versoening asook persoonlike, kerklike en sosiale genesing (2.7).

Die ondertekenaars beroep hulle vir hulle standpunt op die Skrif, die gereformeerde tradisie (Calvyn) en sinodebesluite van die GKSA.

'n Kritiekpunt wat teen die SP ingebring is, is dat dit slegs 'n skuldbelydenis bevat en nie ook 'n getuienis nie. In die eerste ontwerp daarvan was wel 'n getuienis ingesluit, maar die ondertekenaars het na beraadslaging geoordeel dat 'n getuienis die skerp kant van 'n skuldbelydenis sou afstomp. In die "verantwoording" word wel daarna verwys dat die ondertekenaars ook bekommerd is oor die groot knelpunte wat in die land ondervind word (2.5). "Verkeerde dinge van die hede mag [egter] nie as verskoning aangevoer word waarom misdade van die verlede nie bely behoort te word nie" (2.5). Dit is nie uitgesluit nie dat 'n getuienis nog in die toekoms gelewer sal moet word - maar dan moet dit met geloofwaardigheid en vrymoedigheid gedoen kan word.

\subsection{Die vraag na die subjek van 'n skuldbelydenis}

Die vraag ontstaan of, indien so 'n belydenis nodig sou wees, dit deur die kerk (sinodaal en lokaal) gedoen behoort te word of deur individue. Dalk deur die nasie/volk? Sake-instellings?

Oor die standpunt en optrede van die kerke in Suid-Afrika word 'n verpletterende bevinding gemaak: "Christianity, as the dominant religion in South Africa, promoted the ideology of apartheid in a range of different ways" (TRC, 1998, 4:91). Ons het reeds daarop gewys dat die NGK en GKSA vanweë uiteenlopende redes teen sodanige skuldbelydenis besluit het - en inderdaad is dit nie 'n 
probleemlose aangeleentheid nie (vgl. Honecker, 1986:132-158; Villa-Vicencio, 1998:191). Tog is dit nie vreemd aan die reformatoriese tradisie nie.

Berou en skuldbelydenis speel 'n baie belangrike rol in die teologie van Calvyn. Volgens Calvyn bestaan die hoofsom van alle wysheid uit Godskennis en selfkennis (Institusie, 1.1.1), terwyl selfkennis veral bestaan in sondekennis (2.1.1). Die hele evangelie bestaan uit twee sake, naamlik berou en sondevergifnis (3.3.1), wat sodanig met mekaar saamhang dat berou wel nie die oorsaak van sondevergifnis is nie, maar dat sondevergifnis ook nooit sonder berou voorkom nie (3.4.3). Calvyn beskou iemand vervloek wat nie voor God, sy engele, die kerk, ja, voor alle mense bely dat hy 'n sondaar is nie (3.4.6). Ook 'n openbare skuldbelydenis is nodig, voor God en die mense; "so dikwels as God se heerlikheid of ons eie vernedering dit vereis, volg op 'n verborge belydenis wat voor God is, ook 'n vrywillige belydenis voor mense" (3.4.10). Met verwysing na Esra en Nehemia skryf Calvyn: "Hierdie soort gewone belydenis behoort trouens algemeen in die kerk voor te kom en dit behoort ook buiten die gewone op 'n sodanige manier gebruik te word as dit gebeur dat 'n volk hom aan die een of ander algemene sonde skuldig maak" (3.4.11). Volgens Calvyn behoort volksondes dus ook in 'n kerklike belydenis te resoneer. Ons mag volgens Calvyn nie met 'n selektiewe sondebegrip in die kerk werk waar politieke sondes uitgesluit is nie. Anders gesê: ons mag nie in die kerk van totale verdorwenheid praat en in die politiek van die onbevlekte ontvangenis van die mens nie.

Luther oordeel (soos ook Calvyn) dat die bieg altyd vrywillig en sonder dwang moet plaasvind. Tog is die bieg noodsaaklik en moet dit plaasvind "solank ons lewe; want daarin bestaan eintlik ons Christelike lewe, dat ons sal besef dat ons sondaars is en om genade sal smeek" (Luther, 1965:134). Wie nie bieg nie, is eintlik nie 'n Christen nie (Luther, 1965:137-138). Volgens Luther kan ons God nie meer prys nie as om ons sondes te bely (Schulze, 1978:187; vgl. Kamphuis, 1982:183-206).

Hoewel Kuyper in sy opstel oor Calvinisme en religie nie skuldbelydenis eksplisiet aan die orde stel nie, wys hy (1959:44) daarop dat die Calvinis so deur die heiligheid van God aangegryp word "dat het schuldbezef zijn ziel verscheurt en de schrikkelijkheid der zonde hem met centenaarsgewicht op het gemoedt drukt". Hy voeg hieraan toe dat die Calvinisme die bron van menslike ellende die sonde - die diepste gepeil het.

Ook die Duitse teoloog Dietrich Bonhoeffer (1966:117-123) was - as egte Lutheraan - van mening dat persoonlike en kerklike skuld voor God bely moet word (vgl. De Gruchy, 1989:32-45; Fischer, 1982:170-173; Botha, 1989; Smit, 1996:107-108) - vergelyk in hierdie verband die Bekentenis van Bethel (1933). 'n Skuldbelydenis mag egter nooit as goeie werk gesien word nie, mag nie in vaaghede omhul word nie en moet konkrete sondes ter sprake bring (Bonhoeffer, 
1954:91). Tot die struktuur van die verantwoordelike etiese handeling hoort die bereidheid om, soos Christus, skuld op jou te neem (Bonhoeffer, 1966:255-256). Belangrik is dus 'n plaasvervangende belydenis.

Die vraag ontstaan wat individuele gelowiges wat behoefte het aan 'n openbare skuldbelydenis, moet doen indien 'n sinodale verantwoording - om watter rede ook al - agterweë bly. Die antwoord is voor die hand liggend: dan moet die amp van gelowige sterk funksioneer. Hoewel die Skrif duidelik opening gee dat "kerkleiers" namens gelowiges sondes mag bely (Esra 10:1; Neh. 1:6, 9:2; Dan. 9:5, 20), het die vier ondertekenaars van die SP nie so ver gegaan nie. Hulle het 'n beskeie weg gevolg en nie "namens" die GKSA plaasvervangend skuld bely nie. Hulle bedoeling was duidelik om hulle persoonlike skuld as gereformeerde Christene te bely. Soos Dawid en Augustinus.

Behoort 'n nasie nie ook skuld te bely nie? Behoort regeringsleiers dit nie te doen nie? John Kane-Berman het die bewering gemaak dat blanke kiesers in 1992 iets belangrikers as enige belydenis gedoen het, naamlik om met hulle stemreg apartheid te beëindig (aangehaal deur Giliomee, 1998:199; vgl. Krog, 1998:112113). Inderdaad was die blanke referendum van 1992 'n grootse gebeurtenis van politieke selfverloëning (hoewel die meeste blankes toe waarskynlik eerder aan magsdeling as aan magsoorgawe gedink het.) Of dit egter belangriker as skuldbelydenis geag moet word, is te betwyfel. Nou is dit waar dat die voormalige staatspresident, mnr. F.W. de Klerk, by ten minste drie geleenthede 8 verskoning gevra het vir en sy spyt uitgespreek het oor die ellende wat apartheid veroorsaak het, maar 'n ondubbelsinnige en openbare skuldbelydenis sou net soveel groter trefkrag besit het. Dat talle sake-ondernemings, wat deur die beleid van apartheid eensydig bevoordeel is, ook voorleggings aan die WVK gemaak het, moet verwelkom word (Krog, 1998:239-241; TRC, 1998, 4:18-58).

\subsection{Die vraag na die objek van 'n skuldbelydenis}

'n Volgende belangrike vraag wat ons aandag vra, handel oor die vraag teenoor wie 'n skuldbelydenis uitgespreek behoort te word. Moet dit slegs teenoor God uitgespreek word, soos mnr. P.W. Botha van oordeel is (Krog, 1998:266), of ook teenoor die naaste? En waar pas die Waarheids- en Versoeningskommissie (WVK) in?

Daar was by die ondertekenaars van die SP geen twyfel daaroor nie dat skuld voor alles teenoor God bely moet word. Want selfs wanneer misdade teenoor medemense begaan word, soos Dawid se owerspel en moord, dan is dit nog altyd sonde teen God: "Teen U alleen het ek gesondig" (Ps. 51:6; vgl. Jak. 4:8-10). openbare TV-uitsending; op 14 Mei 1997 tydens 'n voorlegging aan die WVK. 
Waar skuld ook al bely word - in die binnekamer, in die liturgie, in 'n sinode, selfs voor die WVK - altyd moet dit gaan oor 'n skuldbelydenis voor God (Calvyn, Institusie, 3.4.9).

'n Tweede aspek is onlosmaaklik hiermee verbind en dit is die skuldbelydenis teenoor die naaste, 'n gedagte wat ons ook duidelik in die Skrif vind (Jak. 5:16). Ons het reeds daarop gewys dat Calvyn (3.4.10) duidelik uitgespreek het dat op 'n verborge belydenis voor God 'n vrywillige belydenis voor die naaste moet volg.

In hierdie verband skiet sowel die SP as die Ope brief te kort. Dit kom 'n situasie kort waar skuldenaars en teenparty saam byeen is, waar enersyds skuld bely en andersyds skuld vergewe kan word - soos tydens die Rustenburg-konferensie van 1990 gebeur het. Ons kom later hierop terug.

Dit alles laat die vraag ontstaan of die WVK nie tog 'n belangrike versoeningsplatform (ge-)bied (het) nie. Besit die Kommissie nie 'n sekere legitimiteit veral by swart mense nie? Die ondertekenaars van die SP het geoordeel dat hulle, sonder om die "noodsaaklike werk" van die WVK te diskrediteer, vir 'n ander metode moet kies, naamlik publikasie in Woord en Daad - al het twee ondertekenaars later in persoonlike hoedanigheid voor die WVK verskyn. Daarmee is uitdrukking daaraan verleen dat daar ook ander legitieme maniere van skuldbelydenis bestaan, soos trouens ook die geval is met die Ope brief.

Dit is waar dat daar vanuit verskeie oorde ernstige kritiek teen die WVK uitgespreek is, dat dit as kommissie van "waarheid en wraaksug" getipeer is wat "kopskote teen die Boere" skiet (Die Burger, 22 Des. 1997); dat dit selektief en eensydig met die waarheid omgaan en meer ' $n$ instrument van die ANC is as instrument van waarheid en versoening. Slegs na 'n indringende studie van die volledige verslag sal hierdie vrae op verantwoorde wyse beantwoord kan word. Sonder twyfel is die WVK beter as niks, ook beter as iets ergers (vgl. De Villiers, 1996:140-153). Dis veel beter as Nürnbergverhore. Dit kan 'n instrument van heling wees, al kan dit nie alle infeksies voorkom nie.

Dit is waar dat die kerk die eintlike en Godgegewe versoeningsinstrument in hierdie land is en die kerk sal ook lank nadat die WVK sy taak afgehandel het, as versoeningsinstituut moet bly funksioneer. Daar rus op kerke 'n ontsaglike groot taak om die boodskap van versoening in die Suid-Afrikaanse samelewing uit te dra en uit te leef (Kistner, 1996:73). Maar dan moet duidelik besef word dat "die kerk versoening slegs kan verkondig as hy self die beeld van 'n versoende gemeenskap vertoon" (Du Plessis, 1987:102). 


\subsection{Die vraag na die doel van skuldbelydenis}

Drieërlei doelstelling kan hier onderskei word en dit kan in drie woorde weergegee word: bevryding, vergewing en versoening (vgl. Van Wyk, 1998:8184, asook Van Wyk, 1993a:13-15).

Skuldbelydenis is 'n manier om die skuld van die verlede te verwerk, om daarmee in die reine te kom, om daarvan bevry te word. Wie sy/haar skuld bely, word daarvan bevry. Dít is nie net 'n psigologiese noodsaaklikheid nie maar ook 'n teologiese waarheid. "Wie sy sonde wegsteek, moet niks goeds te wagte wees nie; wie sy sonde bely en daarvan afsien, sal genade ontvang" (Spr. 28:13).

Meer nog, skuldbelydenis is op versoening gerig. Maar versoening, vergewing en skuldbelydenis staan in die nouste verband tot mekaar. Daar kan kwalik sprake van versoening wees as daar nie vergewing plaasvind nie, en daar kan kwalik vergewing plaasvind as daar nie skuldbelydenis plaasvind nie. Skuldbelydenis en versoening is op interaktiewe wyse met mekaar verbind: "Skuldbelydenis sonder vergifnis en versoening is futiel net soos versoening sonder skuldbelydenis en vergifnis leeg is" (Olivier, 1997:110; vgl. Müller, 1982:185). Ons het reeds eerder na Calvyn verwys volgens wie sondevergifnis nooit sonder berou kan voorkom nie, al is berou nie die oorsaak van vergifnis nie (vgl. Berkouwer, 1960:171).

Dit is waar dat Christene mekaar onbeperk moet vergewe (Ef. 4:32), ja, sewentig maal sewe (Matt. 18:22), maar dit is ook waar dat daar vir vergifnis "gesoebat" en "gesmeek" sal word (Matt. 18:26, 29). Wie nie om vergifnis pleit nie (en self vergifnis skenk), kan nie verwag om self vergifnis te ontvang nie (Mark. 11:2526). Die vergifnis aan die broer loop hand aan hand met sy berou en sy skuldbelydenis van "ek is jammer" (Luk. 17:3-4).

Die verhaal van die bekering van die Nineviete illustreer hierdie waarheid konkreet. Nineve was 'n stad van groot onreg en geweld (Jona 3:8) en sy ondergang word gevolglik aangekondig. Daar tree egter berou en bekering in (3:5-10) - en vergewing volg (3:10), want God is 'n genadige en barmhartige God, lankmoedig en vol liefde (4:2). Vergewing hang nie af van bekering nie, maar hang daarmee saam (vgl. Smit, 1996:103).

Natuurlik is dit waar dat versoening binne die kerk (tussen gelowiges) 'n kwaliteit en diepte besit wat dit nie in die samelewing (tussen gelowiges en ongelowiges) kan hê nie, maar daarmee is nie gesê dat die Bybelse versoeningsboodskap vir die samelewing irrelevant is nie. Inteendeel, Christene word opgeroep om met alle mense in vrede te leef (Rom. 12:18). Oor die teologiese betekenis van versoening bestaan uitgebreide literatuur sodat hier nie breedvoerig daarop ingegaan sal word nie (vgl. Berkouwer, 1953:279-325; 1960:174-204; Ridderbos, 1966:197-222; Jonker, 1977:194-204; Meijers, 
1988:213-224; Wentsel, 1991:387-486; vir 'n Katolieke benadering, kyk Hay, 1998). Versoening (hilasmos) (1 Joh. 2:2, 4:10) beteken om sonde te bedek en skuld uit te delg, terwyl versoening (katallage) (Rom. 5; 2 Kor. 5) beteken om 'n gebroke verhouding te herstel, vrede te bring en vyandskap op te hef. Daar heers groot eenstemmigheid dat versoening ook vir die sosiale etiek betekenis het (Jonker, 1977:205-213; Lekkerkerker, 1966:67-91; Ridderbos, 1972:63-73; Vorster, 1997:4-15). Versoening is ook broodnodig in die Suid-Afrikaanse konteks (Vorster, 1986; Nürnberger \& Tooke, 1988; Van der Walt, 1995:49-54; 1997:14-18).

Versoening (as vrede) is wel verniet maar nie goedkoop nie (König, 1995:114112). Versoening is immers ondenkbaar sonder skuldbelydenis en berou (Luk. 15:18, 18:13; Matt. 18:26; Lekkerkerker, 1996:67-91).

Versoening vind nie sonder skuldbelydenis plaas nie en ook nie sonder vergifnis nie. Skuldbelydenis roep om 'n reaksie van die kant teen wie oortree is; skuld wat bely is, vra om vergewe te word (Müller, 1982:184; Fischer, 1982:173-174). Dis onmoontlik vir die ander party teenoor wie skuld bely is en vir wie vergifnis gevra word om neutraal of vryblywend te bly. Soos wat daar 'n noodsaak is vir 'n skuldbelydenis, so is daar ook 'n noodsaak vir vergewing en versoening. Solank as wat 'n (swart) reaksie (van vergifnis) uitbly, solank bly vergewing en versoening 'n ongerealiseerde ideaal en solank bly die samelewing ongenees. Volgens die Skrif staan nie net hulle wat geen berou het onder die oordeel van God nie, maar ook hulle wat nie bereid is tot vergifnis nie (Matt. 18:35).

Ten opsigte van die reaksie op die SP, gaan dit veral oor die reaksie van swart mense en is die reaksie van blankes daarop grotendeels irrelevant. Die fokus van die SP is immers (veral) die benadeelde en nie die bevoordeelde nie. ${ }^{9}$

'n Laaste aspek moet hier aangeraak word en dit is Deist (1996:9; 1997:33-36) se standpunt dat daar wel vergifnis mag wees maar nooit mag die wandade van die verlede vergeet word nie. Deist se standpunt hou steek vir sover die sondes van die verlede nie bely en vergewe is nie, maar waar dit wél bely en vergewe is, moet dit inderdaad ook vergeet word. Die Here werp ons sondes immers agter sy rug weg (Jes. 43:25; Jer. 31:34; Heb. 10:17). Christene, wat die beeld van God vertoon, word juis opgeroep om mekaar te vergewe soos God in Christus hulle vergewe het (Ef. 4.32). Die liefde bedek alles en hou nie boek van die kwaad nie (1 Kor. 13:5, 7). Hilasmos beteken dat die sonde bedék word.

Miskien moet hier nog fyner onderskei word. Misdade van die verlede wat bely is, mag wel "onthou" word, maar dan nie meer as herinnering aan onopgeloste skuld nie, maar as vergewe skuld, nie meer as aanklag vanuit die verlede nie maar

9 Persoonlik het ek van ons swart broeders net positiewe reaksie op die SP ontvang. 
as uitdaging vir die toekoms. Die herinnering aan misdaad word tegelykertyd ook 'n herinnering aan skuldbelydenis, vergifnis en versoening. Sentraal staan dan nie herinnering aan die versoeningswerk van Christus waarvolgens God met my reken "asof ek nooit sonde gehad of gedoen het nie" (HK 23:60). Die herinnering kom dan binne 'n totaal ander konteks te staan (vgl. Smit, 1996:116).

Dit bring ons by die volgende belangrike vraag: is versoening moontlik sonder vergoeding (restitusie)?

\subsection{Die vraag na regstellende aksie en skuldbelydenis}

'n Konkrete voorbeeld illustreer die vraagstelling: as ek iemand se fiets gesteel het, en ek sê vir hom ek is jammer daaroor en vra dat hy my moet vergewe, maar ek gee die fiets nie terug nie, kan daar dan ooit sprake van vergifnis en versoening wees (vgl. Krog, 1998:109)? Elkeen sal erken dat dit ondenkbaar is.

Reeds in die teologie werk dit so dat versoening nie kan plaasvind sonder voldoening nie, sonder dat die skuld betaal word nie. ${ }^{10}$ Die vraag is dus dringend of daar nie na analogie van die dogmatiese prinsipe van "versoening deur voldoening" ook 'n etiese prinsipe ontwikkel moet word van "versoening deur vergoeding" nie. Word rekonsiliasie nie goedkoop gemaak indien kompensasie nie plaasvind nie? Behoort restitusie nie wesenlik deel te wees van die versoeningsproses nie?

Dit is opvallend dat hierdie aspek sowel in die SP as in die Ope brief behandel word. In die SP staan: "Van ons kant onderneem ons om sover menslik moontlik in woord en daad te vergoed vir die skade wat ons hulle [die benadeelde en verontregte medegelowiges en medeburgers] deur die onbillike sisteem van diskriminasie aangedoen het" (2.4). In die Ope brief lui dit:

Ons wil ook regstel wat ons nagelaat het deur die armes en verdruktes in die land aan hulle eie lot oor te laat. Daarom verbind ons onsself tot die taak om Christene op te roep en te begelei tot betrokkenheid by aksies wat die sosioekonomiese ongelykheid in ons land sal uitskakel. Hierdie roeping het ons te lank verwaarloos.

Ook Sinode 1970 van die GKSA het na restitusie verwys (GKSA Acta, 1970: $63)$.

Die SP maak melding van "sover menslik moontlik". Dit impliseer dat daar vergoeding en regstellende aksie moet plaasvind, maar dat dit in 'n gebroke wêreld nooit volkome kan wees nie. Daar is sake wat nooit weer herstel kan

10 'n Totaal ander standpunt is te vind by Den Heyer (1997); vgl. hierteenoor Noordegraaf (1998:523); Den Hertog (1998:24-42). 
word nie. Dooies kan nie weer lewendig gemaak word nie. Daarby mag die landsekonomie in die proses van regstelling nie vernietig word nie, omdat dit veral die armes die swaarste sal tref (vgl. Van Wyk, 1996:22-25). Sonder 'n grootse poging van verantwoordelike restitusie mag blankes egter nie tevrede wees nie.

Die standpunt van Boesak (1995:202 e.v.; vgl. 1997:120-130) dat daar geen versoening sonder vergelding kan plaasvind nie, hou teologies nie steek nie (vgl. hieroor Van Wyk, 1996:24). Die gelowiges aan wie Petrus sy eerste brief gerig het, was deur hulle landsburgers baie verontreg en die versoeking was groot om hierdie verontregting te bowe te kom deur onreg met onreg te vergeld, 'n optrede wat Petrus baie duidelik afwys (1 Pet. 2:11-4:19).

\subsection{Die vraag na die Skrifbeskouing en skuldbelydenis}

In die diskussie wat gevolg het na die verskyning van die SP het Gerrie Snyman die vraag gestel of met die val van apartheid nie ook gepaard moet gaan die val van die tradisionele Skrifbeskouing nie. "As bely word dat apartheid verkeerd is, hoe kan die histories-letterlike ['n naïef-realistiese en histories-letterlike] benadering [van die Bybel] nog gehandhaaf word?" (Beeld, 10 Oktober 1997).

Hierop het ek soos volg probeer antwoord (Beeld, 20 Okt. 1997): Dit is nie noodwendig waar dat 'n kritiese teologie (en Skrifbeskouing) op 'n kritiese politiek sal uitloop nie. In Duitsland het juis kritiese teoloë (soos Von Harnack) tydens die Eerste Wêreldoorlog 'n konserwatiewe en nasionalistiese politiek gevolg. In Suid-Afrika bestaan die persepsie dat in die NHKA 'n min of meer kritiese teologie beoefen word, maar dan verbind met 'n konserwatiewe politieke siening. Die omgekeerde is egter ook moontlik. Tydens die Tweede Wêreldoorlog het (neo-)konserwatiewe teoloë soos Barth en Bonhoeffer 'n baie kritiese politiek daarop nagehou. Barth se konklusie was in 'n sekere sin die teenoorgestelde van dié van Snyman. Hy het geredeneer dat die oorsaak van 'n konserwatiewe politiek (van oordrewe nasionalisme) tydens die Eerste Wêreldoorlog wat deur sy Berlynse leermeesters ondersteun is, sy oorsprong gevind het in hulle liberale teologie (wat toe deur Barth verwerp is). "An ihrem 'ethischen Versagen' zeigte sich, dass auch ihre exegetischen und dogmatischen Voraussetzungen nicht in Ordnung sein könnten" (vgl. Busch, 1976:93). Ook in Suid-Afrika is daar voorbeelde waar 'n konserwatiewe teologie met 'n kritiese politiek verbind is (Jonker, 1991:97). Konserwatiewe teologie kan dus ook maatskappy-krities wees. Met die val van apartheid val dus nie noodwendig 'n konserwatiewe teologie (en Skrifgebruik) nie, maar wel slegte gereformeerde teologie - soos die Gereformeerde ekumene deurgaans teenoor Suid-Afrikaanse teoloë en kerke volgehou het. 
Hiermee is natuurlik geensins verbygesien dat ook in die gereformeerde teologie (en Skrifgebruik) soms uiters slordig met die Skrif omgegaan word nie, byvoorbeeld in die teologiese regverdiging van apartheid. Die politieke resultate van kritiese realisme is nie noodwendig beter as dié van naïewe realisme nie. Teologies sal ons na 'n weg moet soek tussen fundamentalisme en kritisisme deur.

Oor die vraag hoe dit moontlik kon wees dat 'n ideologie soos apartheid in 'n gereformeerde konteks kon gedy, kan 'n verhaal van sy eie geskryf word (vgl. Van Wyk, 1986:2-3). Dit toon aan ons die ontsettende suigkrag van 'n ideologie en die verblindende effek van die sonde. Dit dui ook daarop dat elke mens in sy diepste wese 'n rassis is. "Het racisme is diep geworteld in de mens"; "de racist en onderdrukker zit in kiem in ieder mens" (Wentsel, 1987:644, 646). Dit blyk duidelik uit die Britse imperialisme, die Nederlandse kolonialisme, die Duitse nasionaal-sosialisme, die Russiese kommunisme, die Amerikaanse neoimperialisme en die Afrikaner-apartisme. Onnodig om op te merk dat Afrikanasionalisme nie outomaties teen verabsolutering gevrywaar is nie.

\section{Slot}

Verontskuldiging is deel van die oersonde van die mens. Dit begin met Adam en Eva en beweeg van toe af soos 'n massiewe stoomroller deur die geskiedenis van die mensdom. Skuldbelydenis is steeds een van die moeilikste dinge om te doen. Van nature wil elke mens homself graag regverdig. Hy/sy wil nie van genade en vergewing leef nie. Tog is skuldbesef en skuldbelydenis - soos ook versoening en vergewing - wesenlik deel van die Christelike boodskap en die Christelike lewe. 'n Sterk sondebesef is juis 'n tipies Christelike verskynsel en word nie so sterk in ander godsdienste gevind nie. Sonde moet egter volgens die Skrifgetuienis bely en gelaat word.

Die ondertekenaars van die SP kon nie anders nie. Hulle was, deur die Gees van God in hulle gewete aangeraak, gedronge om in die openbaar oor 'n groot sonde skuld te bely. Dit is sonder pretensie gedoen, in diepe ootmoed en nooit met die idee dat dit 'n verdienstelike werk sou kon wees nie. In die openbaar het die sonde gedy, in die openbaar was dit nodig om te bely.

Soli Deo gloria 


\section{Bibliografie ${ }^{11}$}

ALBERTS, L. \& CHIKANE, F. ed. 1991. The road to Rustenburg: the church looking forward to a new South Africa. Kaapstad : Struik.

ASCHERMANN, H. 1970. Zondebelijdenis. (In Reicke, B. \& Rost, L. red. Bijbels-historisch woordenboek 6. Utrecht : Spectrum. p. 151.)

BARTH, K. 1978. Die Kirchliche Dogmatik 4/2. Zürich : Theologischer Verlag.

BERKOUWER, G.C. 1953. Het werk van Christus. Kampen : Kok.

BERKOUWER, G.C. 1960. De zonde II. Kampen : Kok.

BOESAK, W. 1995. God's wrathful children: political oppression and Christian ethics. Grand Rapids : Eerdmans.

BOESAK, W. 1997. 'n Swart teologie van land: die Suid-Afrikaanse problematiek. (In Jones, C. \& Hulley, L. red. Wonder jy ook oor ...? Gedagtes oor omstrede kwessies van ons dag. Kaapstad : Lux Verbi. p. 120-130.)

BONHOEFFER, D. 1954. Life together. London : SCM.

BONHOEFFER, D. 1966. Ethik. München : Kaiser.

BOTHA, J.G. 1989. 'n Sistematies-teologiese ondersoek na die rol van die skuldvraag in die denke en praxis van Dietrich Bonhoeffer tussen die jare 1924-1945. Bellville : UWK. (Proefskrif.)

BRINK, A.P. 1979. 'n Droë wit seisoen. Emmerentia : Taurus.

BRINK, A.P. 1984. Die muur van die pes. Kaapstad : Human \& Rousseau.

BUSCH, E. 1976. Karl Barths Lebenslauf. München : Kaiser.

BUYS, A.L.A. 1997. Belydenis oor apartheid: 'n onheilige ruiltransaksie. Waarheid en Dwaling, 3(33):1-3, Nov.

BUYS, A.L.A. 1998. Die derde weg - teen menseregte en diktatuur. Waarheid en Dwaling, 4(1):2-4, Jan.

CALVYN, J. 1984-1992. Institusie van die Christelike godsdiens 1559 (1-4). Vertaal deur H.W. Simpson. Potchefstroom : CJBF.

CAMERON, T. \& SPIES, S.B. red. 1991. Nuwe geskiedenis van Suid-Afrika. Kaapstad : Human \& Rousseau.

COETSEE, D.C. 1997. 'n Openbare skuldbelydenis - 'n bydrae tot waarheid en versoening? Woord en Daad, 362:13, 20-22, Somer.

COETZEE, D.C. 1997. Woord en Daad, 362:13, 20-22.

DEDDENS, K. 1995. Rond de schuldbelijdenis in de liturgie. In die Skriflig, 29(3):491-529, Sept.

DE GRUCHY, J.W. 1989. Confessing guilt in South Africa today. (In Masemola, S. et al. Confessing guilt in South Africa: the responsibility of churches and individual Christians. Braamfontein : SACC. p. 32-45.)

DE GRUCHY, J. 1991. Liberating reformed theology: a South African contribution to an ecumenical debate. Grand Rapids : Eerdmans.

DE GRUCHY, J.W. 1998. Recovering ecumenical vision and commitment in a postecumenical era. Journal of Theology for Southern Africa, 102:1-12, Nov.

DEIST, F. 1996. Vergewe en onthou. Die Kerkbode: 9, Nov. 15.

11 Die volgende twee boeke was ten tye van die finalisering van die artikel nog nie beskikbaar nie:

COCHRANE, J., DE GRUCHY, J.W. \& MARTIN, S. eds. 1999. Faith communities face the truth. Kaapstad : David Philip.

MEIRING, P. 1999. Kroniek van die Waarheidskommissie: op reis deur die verlede en die hede na die toekoms van Suid-Afrika. Vanderbijlpark : Carpe Diem. 
DEIST, F. 1997. Vergewe en vergeet: oor waarheid en versoening in Christelike perspektief. Pretoria : Van Schaik.

DEN HERTOG, G.C. 1998. 'Verstaat gij wat gij leest?' Hermeneutische en bijbelstheologische notities bij de recente discussie over de verzoening. Theologia Reformata, 14(1):24-42, Maart.

DEN HEYER, C.J. 1997. Verzoening: bijbelse notities bij een omstreden thema. Kampen : Kok.

DE VILLIERS, E. 1996. The challenge to the Afrikaans churches. (In Botman, H.R. \& Peterson, R.M. ed. To remember and to heal: Theological and psychological reflections on truth and reconciliation. Kaapstad : Human \& Rousseau. p. 140-153.)

DU PLESSIS, A., VAN DER WALT, B., VAN WYK, A. \& VENTER, P. 1997. Openbare belydenis. Woord en Daad, 361:16-17, Lente. (Afgekort as SP.)

DU PLESSIS, I. 1987. Versoening - gister en vandag: perspektief vanuit Kolossense 1:20 en 22. (In Breytenbach, C. red. Eenheid en konflik: eerste beslissinge in die geskiedenis van die Christendom. Pretoria : NG Kerkboekhandel. p. 89-104.)

FISCHER, H. 1982. Der Schuldbegriff im Kontext heutiger theologischer Antropologie. (In Handbuch der christlichen Ethik 3: Wege ethischer Praxis. Basel : Herder Freiburg. p. 160-180.)

GKSA: Handelinge Nasionale Sinode 1970. Potchefstroom : Administratiewe Buro van die GKSA. (Afgekort as Acta.)

GKSA: Handelinge Nasionale Sinode. 1991. Potchefstroom : Administratiewe Buro van die GKSA.

GKSA: Handelinge Nasionale Sinode. 1997. Potchefstroom : Administratiewe Buro van die GKSA.

GILIOMEE, H. 1998. Die bitter en soet van apartheid. Insig: 12-19, Mei.

GRESCHAT, M. Hg. 1982. Die Schuld der Kirche: Dokumente und Reflexionen zur Stuttgarter Schulderklärung vom 18/19 Oktober 1945. München : Kaiser.

HAY, M. 1998. Ukubuyisane: reconciliation in South Africa. Pietermaritzburg : Cluster.

HONECKER, M. 1986. Geschichtliche Schuld und kirchliches Bekenntnis: die sogenannte Stuttgarter Schulderklärung. Theologische Zeitschrift, 42(2):132-158.

JAFTA, L. 1989. Old Testament background for a confessing church. (In Masemola, S. et al. Confessing guilt in South Africa: the responsiblity of churches and individual Christians. Braamfontein : SACC. p. 46-57.)

JANSEN, H. 1983. Christelijke theologie na Auschwitz I: theologische en kerkelijke wortels van het antisemitisme. 's-Gravenhage : Boekencentrum.

JASPERS, K. 1947. Die Schuldfrage: Ein Beitrag zur deutschen Frage. Zürich : ArtemisVerlag.

JONKER, W.D. 1977. Christus, die Middelaar. Pretoria : NG Kerkboekhandel.

JONKER, W.D. 1991. Die noodsaak van skuldbelydenis. (In De Villiers, E. \& Kitching, D. red. Derdegelui vir môre: die NG Kerk voor die uitdagings van 'n nuwe tyd. Kaapstad : Tafelberg. p. 94-102.)

JORDAAN, G.J.C. 1997b. Algemene Kerkbode: 7, Nov. 14/15.

JOUBERT, E. 1979. Die swerfjare van Poppie Nongena. Kaapstad : Tafelberg.

KAMPHUIS, J. 1982. Luther over de boete. (In Balke, W. et al. Luther en het gereformeerd protestantisme. 's-Gravenhage : Boekencentrum. p. 183-206.)

KESSLER, K. 1996. Das kollektive Schuldbekenntnis im Alten Testament. Evangelische Theologie, 56(1):29-43.

KISTNER, W. 1996. Schuld und Versöhnung in Südafrika. (In Huber, W. Hg. Schuld und Versöhnung in politischer Perspektive: Dietrich-Bonhoeffer-Vorlesungen in Berlin. Gütersloh : Gütersloher Verslagshaus. p. 55-74.) 
KÖNIG, A. 1995. Versoening: Goedkoop? Duur? Verniet? Kaapstad : Lux Verbi.

KÖNIG, A. 1996. Die Kerkbode: ? Mei 14.

KROG, A. 1998. Country of my skull. Johannesburg : Random House.

KUYPER, A. 1959. Het Calvinisme: zes Stone-lezingen. Kampen : Kok.

LANDMAN, Ruda, 1998. Insig: 34, Des.

LEKKERKERKER, A.F.N. 1966. Het evangelie van de verzoening: de tussenmuur weggebroken. Baarn : Bosch \& Keuning.

LUTHER, M. 1965. De grote catechismus. (Vert. P. Boendermaker.) Kampen : Kok.

MAARTENS, M. 1998. Marike: 'n reis deur somer en winter. Vanderbijlpark : Carpe Diem.

MEIJERS, S. 1988. De klassieke verzoeningsleer in de ethische branding; enkele stellingen. Theologia Reformata, 31(3):213-224, Sept.

MICHEL, O. 1967. Hoomologeoo et al. Theological Dictionary of the New Testament. Grand Rapids : Eerdmans.

MÜLLER, A. 1982. Die Befreiung zur Hoffnung. Wege der Metanoia. (In Handbuch der christelichen Ethik 3: Wege ethischer Praxes. Basel : Herder Freiburg. p. 180-194.)

NICOL, W. 1989. Guilt, confession and forgiveness in the New Testament. (In Masemola, S. et al. Confessing guilt in South Africa: the responsibility of churches and individual Christians. Braamfontein : SACC. p. 58-69.)

NGK. 1997. Dagbestuur van die Algemene Sinodale Kommissie. Die verhaal van die Ned. Geref. Kerk se reis met apartheid: 1960-1994, 'n getuienis en 'n belydenis. Wellington : Hugenote-Uitgewers.

NOORDEGRAAF, A. 1998. De verzoening in het Nieuwe Testament. Theologia Reformata, 41(1):5-23, Maart.

NÜRNBERGER, K. \& TOOKE, J. 1988. The cost of reconciliation in South Africa. Kaapstad : Methodist Publishing House.

OLIVIER, H. 1997. Skuldbelydenis en versoening - 'n Ou-Testamentiese perspektief. Ned. Geref. Teologiese Tydskrif, 38(1 \& 2):102-114, Junie.

PRETORIUS, F. 1998. Die Anglo-Boereoorlog 1899-1902. Kaapstad : Struik.

RIDDERBOS, H. 1966. Paulus: ontwerp van zijn theologie. Kampen : Kok.

RIDDERBOS, H. 1972. Zijn wij op de verkeerde weg? Een bijbelse studie over de verzoening. Kampen : Kok.

SCHULZE, L.F. 1978. Geloof deur die eeue. Pretoria : NG Kerkboekhandel.

SMIT, D. 1996. Confession-guilt-truth-and-forgiveness in the Christian tradition. (In Botman, H.R. \& Peterson, R.M. ed. To remember and to heal: theological and psychological reflections on truth and reconciliation. Kaapstad : Human \& Rousseau. p. 96-117.)

SP

kyk Du Plessis et al. 1997.

STROBEL, A. 1968. Erkenntnis und Bekenntnis der Sünde in neutestamentlicher Zeit. Stuttgart : Calwer.

TRUTH AND RECONCILIATION COMMISSION OF SOUTH AFRICA REPORT 1-5. 1998. Kaapstad : TRC/Juta. (Afgekort as TRC.)

VAN DER WALT, B.J. 1995. Die hand in eie boesem: 'n besinning oor Afrikaner-identiteit. Potchefstroom : PU vir CHO. (IRS.)

VAN DER WALT, B.J. 1997. 'n Skuldbelydenis oor apartheid. Potchefstroom : PU vir CHO. (IRS - studiestuk nr. 358a.)

VAN DER WALT, B.J. \& VENTER, J.J. 1998. Godsdiens en samelewing/Religion and society: a review of the Truth and Reconciliation Commission hearings, East London, 17-19 November 1997. Potchefstroom : PU vir CHO. (IRS - studiestuk nr. 361.) 
VAN WYK, I.W.C. 1997. Moet die Afrikaanse kerke skuld bely oor apartheid? Wat leer ons uit die Duitsers se worsteling met skuld? Hervormde Teologiese Studies, 53(4):13991436, Nov.

VAN WYK, J.H. 1984. Etiek van vrede: 'n teologies-etiese evaluering van die Christenpasifisme. Stellenbosch : Cabo.

VAN WYK, J.H. 1986. Hoe kon dit alles gebeur het? Woord en Daad: 2-3, Jul.

VAN WYK, J.H. 1993. Homo Dei: 'n prinsipiële besinning oor enkele mensbeskouings, waaronder dié van Calvyn. In die Skriflig, Supplementum 1.

VAN WYK, J.H. 1993a. Skuldbelydenis. Woord en Daad: 343:13-15, Herfs.

VAN WYK, J.H. 1996. Arbeidsetiek: 'n teologies-etiese benadering. Potchefstroom : PU vir CHO. (IRS-studiestuk nr. 346.)

VAN WYK, J.H. 1997a. Gedagtes oor skuldbelydenis. Die Kerkblad, 99(3008):24-25, Maart.

VAN WYK, J.H. 1997b. Debat oor skuldbelydenis. Woord en Daad, 359:4-6, Herfs.

VAN WYK, J. (H.) 1998. The necessity of confession: what difference will it make. (In Du Toit, C.W. ed. Confession and reconciliation: a challenge to the churches in South Africa. Pretoria : Unisa. p. 81-84.)

VAN WYK, J.H. 1998. Reaksie op artikel van A.L.A. Buys. Waarheid en dwaling :3-4, Nov.

VILLA-VICENCIO, C. 1998. The burden of moral guilt: its theological and political implications. (In Kretzschmar, L. \& Hulley, L. eds. Questions about life and morality: Christian ethics in South Africa today. Pretoria : Van Schaik. p. 185-198.)

VORSTER, J.M. 1997. 'n Oorsig van die versoeningsleer by Paulus en die implikasies daarvan vir versoening in Suid-Afrika vandag. Ned. Geref. Teologiese Tydskrif, 38(162):4-15, Jun.

VORSTER, J.M. 1997. Beeld: 11, Okt. 8.

VORSTER, W.S. ed. 1986. Reconciliation and construction: creative options for a rapidly changing South Africa. Pretoria : Unisa.

WENTSEL, B. 1987. Dogmatiek 3a: God en mens verzoend: Godsleer, mensleer en zondeleer. Kampen : Kok.

WENTSEL, B. 1991. Dogmatiek 3b: God en mens verzoend: Incarnatie, verzoening, koninkijk van God. Kampen : Kok.

WENTSEL, B. 1995. Dogmatiek 4a: De persoon en het werk van de Heilige Geest. Kampen : Kok.

WESTERMANN, C. 1978. jdh - preisen. (In Jenni, E. \& Westermann, C. Hrsg. Theologisches Handwörterbuch zum Alten Testament. München : Kaiser. p. 674-682.) 